\title{
Philology
}

An International Journal on the Evolution of Languages, Cultures and Texts

General editor: Francesco Benozzo

Volume 3 / 2017

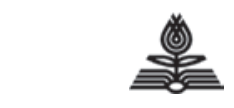

PETER LANG

Bern · Berlin · Bruxelles · New York · Oxford · Warszawa · Wien 


\section{Editorial Address:}

Francesco Benozzo

Università di Bologna

Dipartimento di Lingue, Letterature e Culture Moderne

Via Cartoleria 5

I-40124 Bologna, Italy

francesco.benozzo@unibo.it

\section{Subscriptions:}

Peter Lang AG, International Academic Publishers

Wabernstrasse 40

CH-3007 Bern

Switzerland

Phone +41313061717

Fax +41313061727

E-Mail: info@peterlang.com

www.peterlang.com

1 volume per year

Subscription Rates:

CHF 59.- / €* 52.- / €** 54.- / € 49.- / £ 39.- / US-\$ 64.-

* incl. VAT ( valid for Germany and EU customers without VAT Reg No)

** incl. VAT (valid for Austria)

\section{PETER LANG}
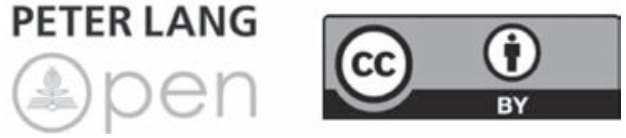

This work is licensed under a Creative Commons

CC-BY 4.0 license. To view a copy of this license, visit https: / / creativecommons.org/licenses/by/4.0/

(C) Peter Lang AG

International Academic Publishers, Bern 2018

Wabernstrasse 40, CH-3007 Bern, Switzerland

bern@peterlang.com, www.peterlang.com

Printed in Germany 


\section{Contents}

Volume III / 2017

Special Session: Languages in European Prehistory

Francesco Benozzo \& Mario Alinei

European Philologies: Why Their Future Lives in

Their Prehistoric Past

MARCEl OtTE

Indo-Europeans Arrived in Europe with Modern Man

JonAthan SHERman Morris

Wheels, Languages and Bullshit (Or How Not To Do

Linguistic Archaeology)

XAVERIO BALLESTER

Some Major Celtic Details on the Origins of

Indo-European Languages

DANIEL LE BRIS

Geolinguistic Continuities in the Celto-Atlantic Area and

in Western Europe

WINFRID SCUTT

Celtic in the Fleuve Manche

DAPHNE NASH BRIGGS

Multilingual Coin Inscriptions and Their Context in

Pre-Roman East Anglia...

Articles

EPHRAIM NISSAN

Gad as an Ancient Semitic Theonym, and Its Lexical Cognates.

With an Exploration of the Semantics of gad, and of

Its Medieval Exegesis. 
Rossano De LaurentiIs

Santafior com'è sicura (Purg. VI 111): When Local Pride

May Not Be Philological.

SusAn Petrilli

Lifelong Listening to M. Bakhtin's Word in the Context of His

"Circle". A Philological Approach by A. Ponzio

Crossings

Francesco BenOZZo

Per un'ecdotica del molteplice e del discordante:

il caso dei manoscritti trobadorici

Notes

REMO BRACCHI

Torus, The Big Bang of Life

Mahmoud Salem Elsheikh

The World of Islam. Historical Prejudices to Overcome

(or Debtor's Syndrome?).

Review article

EPHRAIM NisSAN

Jewish Vernaculars, Their Hebrew Loanwords or

Code-Switching, and the Related Idiomatics 437

Reviews

OndŘej BláHA, Robert DitTMann ANd Lenka Uličná (eds.)

Knaanic Language: Structure and Historical Background

(Ephraim Nissan) 523 
Special Session

\section{Languages in European Prehistory}

Proceedings of the $23^{\text {rd }}$ Annual Meeting of The European Association of Archaeologists (Maastricht, August $30^{\text {th }}-$ September $3^{\text {rd }} 2017$ )

Session 410 / Languages in European Prehistory (organized by Winfrid Scutt \& Marcel Otte)

$$
\text { edited by }
$$

Francesco Benozzo 


\title{
Some Major Celtic Details on the Origins of Indo-European Languages
}

\author{
XAVERIO BALLESTER \\ Universitat de Valéncia
}

\begin{abstract}
A question still open to debate is the unresolved "Celtic conundrum", i.e., the origins of the Celtic-speaking people. The traditional theory postulates that the compact presence of Celtic languages in the extreme west of Europe was also due to an invasion of Celtic people from Central Europe during the first millennium B.C. However, this theory must face a mass of problematic questions and explain some minor but crucial details.
\end{abstract}

Keywords Celtic languages, Proto-Indo-European, Historical Linguistcs

\section{Going into detail: a brief methodological note}

In recent times, diachronic linguistics has begun to take into account the significance of sound consistency with a few concrete details in order to validate a theory wich is both abstract and large. Things were different in protohistoric Linguistics during the $19^{\text {th }}$ and $20^{\text {th }}$ centuries, when scholars used to proceed from top to bottom, from the ensemble concept to the detailed point in a deductive way of reasoning. Concerning the origins of non-historical languages, a standard proceeding was to propose generically a macrotheory based on analogies - but quite often very disputable and necessarily anachronistic analogies - with the well documented origins of historical languages. The most conspicuous example of these practices is probably the traditional and mainstream theory on the origin of the Indo-European languages. According to this megatheory, the presence of Indo-European languages in Europa and in a significant part of Asia was essentially due to a superinvasion of Indo-European people during the end of the Neolithic period and primarily as a result of their military supremacy.

Obviously, the first problem that one must assume to evaluate megatheories of this kind is their - let's say - economic aspect, since their approval or 
rejection implies testing a big amount of archaeological, genetic, geographic, historical or linguistic data.

Another question is the relevance of the subject being studied. Some points can be crucial to encourage us to accept or dismiss the emerging theory and others can be completely irrelevant to the verdict. For example, even if we could demonstrate that Latin was already spoken 1,000 years B.C. in Latium, this piece of evidence would have no major consequences for the mainstream theory on the origins of Indo-European languages. Conversely, if we could demonstrate that Latin was spoken, for example, 10,000 years B.C. - let's say - in the Canary Islands, this new piece of information - if ascertained - would inmediately endorse our firm rejection of the old theory, since the new data would be wholly incompatible with the dates and places defended by the traditional theory.

Seeking the red lines of a theory

Fortunately, all theories have their own red lines, or red lights; limits that you cannot cross. If one does, it means that the theory is not well founded.

On the other hand (and fortunately too), healthy theories have two concomitant qualities: predictivity and productivity, i.e., they must somehow foresee (predictivity) results or data that only further investigation will confirm or refute, since theories necessarily try to cast light on dark aspects of the reality. At the same time, since megatheories involve a constellation of data, their explanatory capacity must be valid for the majority (productivity) and not only for a minority.

Naturally, a theory can be considered erroneous or even false, if its predictions mostly fail or if its productivity is scarce. Incidentally, let us comment that an odd trait of the mainstream Indo-European Linguistics has traditionally been the very low level of its predictive power. Due to the unexpectedness either of place or of time or because of both, the discovery of archaic Indo-European languages in Anatolia, the discovery of Mycenaean Greek - just a mere specimen of old Greek - in Crete or the discovery of a centum language as Tocharian in the far wild East became completely unforeseen surprises in the frame of traditional theory. 


\section{One of the decisive battles: the Celtic conundrum}

So, let's abandon the wide and blurred oceanic horizons for a while to focus our mind on the sharply defined skylines of small islands. A question still open to debate is the unresolved "Celtic conundrum" (Raftery, 1998, p. 273), i.e., the origins of the Celtic-speaking people. The traditional theory postulates that the compact presence of Celtic languages in the extreme west of Europe was also due to an invasion of Celtic people from Central Europe during the first millennium B.C.

Identifying the origin of a language from an invasion and subsequent colonizations or linguistic expansions does not entail too much risk. In this case, for example, we have real and historical documentation of Celtic languages in Western Europe on one side: Celtiberian in Spain, Gaulish in ancient Gaul, Irish, Welsh and Scots in the British Isles etc. On the other side, in central Europe we find several cultural elements - for instance, pottery or some other artefacts - that were more or less coetaneus and similar to those found among the western Celts, so that one can allegedly propose that Western Celts arrived from central Europa around that time.

However, a mass of problematic questions soon started to rise. A major problem, for example, was that scholars could find no evidence, no proof, no sign, or even a trace of a Celtic invasion in the British Isles. As to continental Western Europe, the traces were also quite disputable, while, conversely, eastward invasions of Celtic people - more precisely: Gauls were perfectly recorded by ancient writers in Roman times.

Wars used to have decisive battles and as shown by the Indo-European puzzle the origin of the Celts is a clear example of this. Historically, Celtic-speaking people occupy a very peripheral location in pure geographic terms, since they mostly settled in the extreme western zone of the Indo-European domain. They could only reach their historical headquarters in very recent times, according to traditional theory, because the further you go, the later you arrive, and Celtic tribes supposedly come from an ancestral Indo-European Urheimat far, far away. Therefore, an old date for Celtic-speaking people in the western fringes of Europe can be a crucial argument against traditional scenario, given that a very recent date - Neolithic or Epineolithic age - for Indo-European diaspora represents one of those red lines - no trespassing! - of the theory. 


\section{$\operatorname{Man}[\mathrm{x}]$ continuity or late last comers?}

Alinei, 2000, p. 497, accurately described the Celts as the "main "victims' of the traditional theory", ${ }^{1}$ since they were compelled to appear in their historical homeland right at the last moment, when all or almost all the other Indo-European tribes had already occupied their own respective historical territories. They were simply the late last comers. But this view collides head-on with several little albeit firmly fixed facts.

One is the linguistic history of the Isle of Man. As Alinei \& Benozzo, 2009 , pp. 7-8, point out, the small British island, historical home of the Manx, an ancient Celtic language,

provides archaeological traits that allow us to observe a stable cultural - and also genetic - continuity from its first settlement in the Mesolithic era [...] during millennia, we have no proof of the language spoken on the island, but from the earliest testimonies to the $\mathrm{xx}^{\text {th }}$ century, when Manx was no longer spoken, everything suggests that there the dominant and established language was one of Celtic type. Thus, in the context of stable cultural continuity, to hypothesize that a language of a stock any other than Celtoid was ever spoke in the island is, at best, the least economic and probable hypothesis. ${ }^{2}$

\section{However,}

there is now a wealth of information supporting continuity since the preceding Palaeolithic and Mesolithic periods revealing a slow and gradual adoption of Neolithic elements by local indigenous populations. This is especially true for Atlantic Europe, the very same area that becomes populated with megaliths during the subsequent Neolitithic and Bronze ages (Silva \& Frank, 2013, p. 223).

Indeed, if from the archaeological point of view there is no evidence of any foreign invasion, no evidence of any interruption, neither during the first

1 "le principali «vittime» della teoria tradizionale".

2 "fornece características arqueológicas que permitem observar a sua estável continuidade cultural - e também genética - a partir do seu primeiro povoamento, na época mesolítica [...] durante milénios não temos prova alguma [...] da língua falada na ilha, mas, a partir dos primeiros testemunhos até ao século $\mathrm{xx}$, quando se deixou de falar manês, tudo sugere que, ali, a língua dominante e estabelecida foi de tipo céltico. Assim, neste marco de continuidade cultural estável, a hipótese de pensar que alguma vez se falou uma língua de vinculação diferente da celtóide, é, quando muito, a hipótese menos económica e provável". 
millennium B.C. nor before or later until modern times, if we only find cultural and population continuity on the island, the real question at issue is when and how that people started to speak a Celtic language? ${ }^{3}$ No more questions, your honor.

\section{The meaning of Colonsay}

And now let us introduce a smaller detail, inasmuch since we are going to speak about an island even smaller. As we wrote some years ago:

From a review by Paolo Galloni (2013) [...] we knew of the sensational discovery by the archaeologist Steven Mithen (2004) in a Scottish island of the Hebrides, specifically in Colonsay, a Gaelic word meaning 'hazelnut' ${ }^{2}[\ldots]$ the excavations that were carried out showed that indeed Colonsay had hazelnuts, but only... between the years 8,000 and 5,000 B.C., when nuts were collected almost on an industrial scale. Anyone who has a minimal competence with toponymy knows that place names are usually motivated with much accuracy [...] vegetal names are one of the most common motivations, so that $[\ldots]$ we cannot doubt that the island might be named that way $[\ldots]$ Galloni (2013: 131) hazards two explanations:

1) that was the original place name that the first settlers, who spoke a Celtic language, gave to the island; the descendents of those first settlers would have held the original name until today, although the motivation for such a place name - the hazelnuts - dissapeared some millennia ago,

2) the island would have been so called originally by its first settlers, speakers of an enigmatic language $[\ldots]$ and his name would have been translated into a Celtic language by the Celts themselves when they arrived at the island [...]

Logically, Galloni (2013, p. 131) opts for the first option: “'Obviously, the second hypothesis looks highly improbable' [...] All of this aside from the significant detail that cultural continuity is $[\ldots]$ the rule in this archipelago, where neither discontinuity nor intrusive elements are detected". ${ }^{5}$

3 Mutatis mutandis, the same could be same about a bigger island: Ireland, where "in the cold face of the surviving archaeological remains, there is simply no evidence of invading Celts" (Raftery, 2006, p. 278).

4 More precisely: since Coll is the Gaelic word for 'hazel', Colonsay means 'hazelnut island'.

5 "Através de uma resenha de Paolo Galloni (2013) [...] tivemos a notícia de uma sensacional descoberta do arqueólogo Steven Mithen, numa ilha escocesa do arquipélago das 


\section{A Scottish calendar: they were already there}

As a sensational archaeological discovery was presented some few years ago the so-called "oldest astronomical calendar of the world", dated around 8,000 B.C. (!). This luni-solar "time reckoner" was made up by means of a coherent arrangement of pits aligned from south-west to north-east. However, this was found not in China, Egypt or Sumer but in... Scotland, Aberdeenshire. According to discoverers (uide GAFFNEY \& alii 2013) hunter and gatherer communities had already a deep knowledge of time measurement in the cold lands of Scotland some 5,000 years (!) before the first calendars appeared in the warm sands of Mesopotamia. On the other hand, no man may longer doubt the astronomical function of so many megalithic monuments located in the Atlantic siue Celtic Europe: "there remains the unshakeable fact that a number of our most impressive megalithic tombs were designed $[\ldots]$ to relate precisely to significant solar or lunar events" (Cunliffe, 2004, p. 203). Again, Alinei and Benozzo, 2009, pp. 16-18 (see also 2008a and 2008b) have keenly defended a Celtic origin for European megalithism. Also, Kruta (v.g. 2007) has repeatedly attempted to show that historical Celts held an impressive astronomical expertise and this now seems to be an unshakeable fact. Basically, all these singular pieces of the puzzle can be put together in two different ways:

Hébridas, em concreto em Colonsay, palavra gaélica que significa 'avelã' [...] as escavações efectuadas mostraram que, com efeito, Colonsay tinha tido avelãs, só que... entre 8000 e 5000 a. C., quando as avelãs se colhiam à escala quase industrial. Quem quer que esteja minimamente familiarizado com a toponímia sabe que os nomes de lugares são regularmente motivados com grande precisão e que [...] a referência a plantas ou árvores [...] é uma das motivações mais comuns, pelo que a partir da toponomástica moderna não se pode duvidar de que a ilha podia ter-se chamado assim [...] porque na ilha, em alguma época, teriam crescido efectivamente avelaneiras [...] Galloni (2013: 131) vislumbra estas duas explicações: 1) a ilha teria sido assim denominada originariamente pelos seus primeiros povoadores, de língua céltica, e estes teriam mantido até à actualidade esse nome, embora a sua motivação - a existência de avelaneiras - tivesse desaparecido há milénios; 2) a ilha teria sido assim denominada originariamente pelos seus primeiros povoadores, falantes de uma língua pre-indo-europeia, e o seu nome teria sido traduzido para uma língua céltica pelos próprios Celtas quando estes chegaram a essa ilha [...] Logicamente, Galloni (2013: 131) escolhe a primeira opção: 'É evidente che la seconda ipotesi appare altamente improbabile' [...] Tudo isto à margem do muito significativo pormenor de que a continuidade cultural é [...] a norma neste arquipélago, onde não se detectam nem descontinuidade nem elementos intrusivos". 
1) this knowledge came from a Celtic-speaking people and passed down from generation to generation until historical times,

2) this knowledge originally came from a mysterious pre-Indo-European people who transmitted this wisdom - no one knows when and how - to Indo-Europeans newcomers.

Once again, the simplest explanation is the first one, but this option would involve putting the traditional clock for Indo-European studies back dramatically, a challenge that so far only the proponents of the so-called Paradigm of Palaeolithic Continuity (see (www.continuitas.org)) have seriously taken up, but maybe it's time to turn the chronological deadline and other long-held beliefs upside down.

\section{References}

Alinei, M. (2000). Origini delle lingue d'Europa. II. Continuità dal Mesolitico all'età del Ferro nelle principali aree etnolinguistiche. Bologna: il Mulino.

Alinei, M. - Benozzo, F. (2008a). Megalithism as a Manifestation of an Atlantic Celtic Primacy in Meso-Neolithic Europe. Studi Celtici 6, $13-72$.

Alinei, M. - Benozzo, F. (2008b). Origini del megalitismo europeo. Un approccio archeo-etno-dialettologico. Quaderni di Semantica 29, 295-332.

Alinei, M. - Benozzo, F. (2009). Origens Célticas e Atlânticas do Megalitismo Europeu. Trans. G. Morais. Lisboa: Apenas Livros.

Cunliffe, B. (2004). Facing the Ocean. The Atlantic and its Peoples 8000 $B C-A D$ 1500. Oxford: Oxford University Press.

Gaffney, V. - Fitch, S. - Ramsey, E. et al., (2013). Time and a Place: A luni-solar 'time-reckoner' from $8^{\text {th }}$ millennium BC Scotland. Internet Archaeology 34 http://dx.doi.org/10.11141/ia.34.1〉.

Galloni, P. (2013). Review of D. Le Bris (Ed.). Aires Linguistiques. Aires Culturelles. Études de concordances en Europe occidentale: zones Manche et Atlantique. Brest, 2012, Quaderni di Semantica $34,123-132$. 
Mithen, S. (2004). After the Ice. A Global Human History, 20,000-5,000 $B C$. Cambridge (Mass.): Harvard University Press.

Raftery, B. (2006). Celtic Ireland: Problems of Language, History and Archaeology. Acta Archaeologica Academiae Scientiarum Hungaricae 57, 273-279.

Silva, F. - Frank, R.M. (2013). Deconstructing the Neolithic Myth: The Implications of Continuity for European Late Prehistorty. Anthropological Notebooks 19, 223-235.

〈www.continuitas.org = Official website of the Paleolithic Continuity Paradigm International Workgroup. 